\title{
PENGARUH KONSENTRASI ASAM MONOKLORO ASETAT DAN JENIS PELARUT SEBAGAI BAHAN PENGENDAP TERHADAP PRODUKSI KARBOKSIMETIL KITIN
}

\author{
Th. Dwi Suryaningrum"), Jamal Basmal"), dan Wina Aumeilia")
}

\begin{abstract}
ABSTRAK
Riset pengaruh konsentrasi asam monokhloro asetat $(0,15 ; 0,30$; dan $0,45 \mathrm{~mol})$ dan jenis pelarut organik (metanol dan isopropanol) sebagai pengendap terhadap sifat-sifat karboksimetil kitin dari cangkang rajungan (Portunus pelagicus) telah dilakukan. Hasilnya menunjukkan bahwa rendemen yang dihasilkan tergantung jenis bahan pengendap yang digunakan. Pengendap metanol menghasilkan rendemen makin kecil dengan makin tingginya konsentrasi asam monokloro asetat, sebaliknya dengan pengendap isopropanol semakin tinggi konsentrasi asam monokloro asetat yang digunakan, menunjukkan hasil yang lebih baik pada derajat substitusi, kelarutan dan kekentalan. Pengendap isopropanol menghasilkan rendemen, derajat substitusi, dan kelarutan karboksimetil kitin yang lebih baik dari pada metanol. Namun demikian, derajat deasetilasi dan kekentalan karboksimetil kitin lebih baik jika menggunakan metanol daripada menggunakan isopropanol. Hasil karboksimetil kitin terbaik dihasilkan dari kombinasi perlakuan $0,30 \mathrm{~mol}$ asam monokhloro asetat dan pelarut pengendap metanol, yaitu menghasilkan rendemen sebesar $46,4 \%$, derajat deasetilasi $51,4 \%$, derajat substitusi 0,8 , membutuhkan $26,2 \mathrm{ml}$ air untuk melarutkan $1 \mathrm{~g}$ karboksimetil kitin, viskositas 131,2 cPs, kadar air 8,1\% dan kadar abu $1,9 \%$.
\end{abstract}

ABSTRACT: Effect of monochloro acetic acid concentration and solvent type of as precipitation agent on production of carboxymethyl chitin. By: Th. Dwi Suryaningrum, Jamal Basmal, and Wina Aumeilia

\begin{abstract}
A research on the effect of monochloro acetic acid concentration $(0,15 ; 0,30 ;$ and 0,45 mol) and type of organic solvent (methanol and isopropanol) as precipitation agent on the characteristics of carboxymethyl chitin extracted from swimcrab shell (Portunus pelagicus) has been carried out. The results showed that yield obtained was depended on the type of precipitation agent. Methanol as precipitation agent decreased the yield when the concentration of monokhloro acetic acid increased. In the use of isopropanol, as precipitation agent increasing of monokhloro acetic acid showed better results on degree of substitution, solubility and viscosity. Isopropanol resulted in a better yield, the degree of substitution and solubility than methanol did. However, the degree of deacetylation and viscosity of carboxymethyl chitin were better when using methanol than isopronanol. The best result of carboxymethyl chitin was obtained by using combination treatment of $0.30 \mathrm{~mol}$ monochloro acetic acid and methanol as precipitation agent, resulted in $46.4 \%$ yield, 51.4\% degree of deacetylation, 0.8 degree of substitution, $26.2 \mathrm{ml}$ water to disolve $1 \mathrm{~g}$ carboxymethyl chitin, 131.2 cPs viscosity, $8.1 \%$ of moisture content, and $1.9 \%$ of ash content.
\end{abstract}

KEYWORDS: carboxymethyl chitin, swimcrab shell, characteristics of carboxymethyl chitin

PENDAHIILUAN

Industri perikanan seperti pengolahan udang, kepiting, rajungan dan lobster dapat menghasilkan limbah berupa cangkang yang jumlahnya cukup besar, yaitu berkisar antara $40-60 \%$ untuk udang, dan 75$85 \%$ untuk kepiting (Peranginangin, 2004). Apabila limbah tersebut tidak dima, faatkan akan menimbulkan masalah pencemaran lingkungan. Di lain pihak, limbah tersebut dapat dimanfaatkan sebagai bahan baku industri yang bernilai ekonomi tinggi, karena limbah tersebut adalah sumber utama kitin.
Kitin merupakan biopolimer dengan berat molekul tinggi yang paling banyak terdapat di alam setelah selulosa. Struktur kimianya merupakan polimer dari 2 -asetamido-2-deoksi- $\beta$-D-glukosa yang dihubungkan dengan ikatan $(1 \rightarrow 4)-\beta-$ glikosidik atau disebut juga $\mathrm{N}$-asetil- $\beta$-D-glukosamin (Whistler \& Miller, 1973). Kitin dapat digunakan pada berbagai industri pangan dan non pangan maupun farmasi dan diperkirakan kebutuhan kitin mencapai satu milyar ton setiap tahunnya (Dahuri, 2003).

Kitin memiliki kemampuan sebagai pengikat air, pengikat lemak, koagulan, dan bersifat biodegradable

\footnotetext{
-) Peneliti pada Pusat Riset Pengolahan Produk dan Sosial Ekonomi Kelautan dan Perikanan

*) Mahasiswa Fak. Farmasi Univ. Pancasila
} 
sehingga membuat kitin menjadi bahan baku yang atraktif (Hirano, 1988). Kitin dan derivatnya dapat digunakan sebagai biomedikal dalam berbagai macam tujuan seperti bakteriostatik, kosmetik, spermisidal, sarung tangan operasi, imobilisasi enzim, membran dialisis, kontak lensa, obat luka, antikolesterol, antigastritik, antibilirubin, dan antikoagulan (Olsen et al., 1988).

Salah satu kekurangan kitin adalah sifatnya yang tidak larut air. Kitin larut dalam asam mineral pekat seperti asam asetat, asam klorida, asam sulfat, asam nitrat, asam fosfat, dan asam anhidrat (Anon., 1981), sehingga menyebabkan penggunaan kitin menjadi terbatas. Namun, dalam bentuk turunannya, misalnya karboksimetil kitin, menjadi larut dalam air, bersifat biodegradable, dan biocompatible serta tidak toksik. Karboksimetil kitin banyak digunakan dalam industri kosmetik sebagai pelembab dan sel aktivator untuk menghaluskan dan membersihkan kulit. Selain itu karboksimetil kitin digunakan sebagai antielektrostatik, pelindung rambut, penyerap bau, dan bersifat antibakteri (Samarin et al., 2001).

Untuk membuat karboksimetil kitin dilakukan eterifikasi dengan substitusi gugus karboksimetil pada atom $\mathrm{C}_{6}$. Kitin mempunyai dua gugus hidroksi pada $\mathrm{C}_{3}$ dan $\mathrm{C}_{6}$ dalam tiap monomer $\mathrm{N}$-asetil-D-glukosamin. Gugus hidroksi pada $\mathrm{C}_{6}$ lebih reaktif dari $\mathrm{C}_{3}$. Modifikasi kimia pada gugus-gugus tersebut akan menghasilkan bermacam-macam derivat kitin. Kitin dibedakan dengan kitosan berdasarkan derajat deasetilasinya. Pada kitin derajat deasetilasinya berkisar antara 15$70 \%$ sedangkan kitosan lebih dari 70\% (Bustaman, 1989).

Pembuatan senyawa karboksimetil kitin pada prinsipnya sama dengan pembuatan karboksimetil kitosan, hanya pada preparasi kitosan didahului dengan proses deasetilasi menggunakan $\mathrm{NaOH}$ yang dilakukan pada suhu tinggi. Kondisi tersebut menyebabkan terjadinya depolimerisasi yang membuat gugus asetil semakin mudah dilepaskan, sehingga diperoleh derajat deasetilasi tinggi. Proses tersebut juga akan menyebabkan terjadinya penurunan rendemen, bobot molekul, dan viskositas yang dihasilkan (Shalaby \& Shah, 1991). Untuk menghindari hal ini Sheng et al. (2001) melakukan proses deasetilasi pada suhu beku, dalam kondisi ini derajat deasetilasi tidak sampai $70 \%$ dan tidak terjadi depolimerisasi yang menimbulkan terjadinya fragmentasi polimer dan akhirnya menyebabkan turunnya bobot molekul dan viskositas.

Pada prinsipnya ada 2 tahap yang harus dilakukan untuk pembentukan karboksimetil kitin. Tahap pertama kitin direaksikan dengan natrium hidroksida sehingga menjadi bentuk alkoksida kitin, dimana gugus hidroksil kitin disubstitusi dengan gugus $\mathrm{Na}^{+}$.
Tahap kedua adalah substitusi gugus karboksil (COO) dengan menggunakan asam monokloro asetat dengan alkoksida kitin menjadi karboksimetil kitin. Substitusi gugus karboksil pada gugus hidroksi kitin menjadi karboksilmetil kitin sangat dipengaruhi proses pengolahannya (Bader \& Birkholz, 1997).

Dalam penelitian ini dilakukan pembuatan karboksimetil kitin menggunakan asam monokloro asetat dengan konsentrasi yang berbeda dan jenis pelarut organik (isopropanol dan metanol) sebagai bahan pengendap untuk melihat perbedaan rendemen serta mutu (derajat deasetilasi, derajat substitusi, kekentalan, dan kelarutan) karboksilmetil kitin yang dihasilkan.

\section{BAHAN DAN METODE}

\section{Bahan}

Bahan yang digunakan dalam penelitian ini adalah cangkang rajungan (Portunus pelagicus) yang diperoleh dari limbah pengolahan rajungan di Cirebon. Kulit rajungan kemudian dijemur di bawah sinar matahari sampai kering kemudian dibawa ke Jakarta dengan menggunakan karung plastik. Sedangkan bahan bantu yang digunakan adalah $\mathrm{NaOH}$, asam monokloro asetat, serta bahan kimia lainnya untuk analisis mutu karboksimetil kitin.

\section{Metode}

\section{Ekstraksi kitin}

Untuk memperoleh kitin dari limbah rajungan dilakukan tahapan sebagai berikut (Hong \& Meyer, 1989).

a. Deproteinasi: Deproteinasi dilakukan dengan cara merebus cangkang rajungan dalam larutan $\mathrm{NaOH} 4 \%(1: 10 \mathrm{~b} / \mathrm{v})$, pada suhu $70^{\circ} \mathrm{C}$ selama 2 jam, kemudian dicuci, dan dinetralkan.

b. Demineralisasi: Cangkang rajungan yang telah mengalami deproteinasi direndam dalam larutan $\mathrm{HCl}$ 10\% 1:10 (b/v) selama 5 jam pada suhu kamar sambil diaduk-aduk, kemudian dinetralkan, dan dikeringkan sehingga diperoleh kitin kering.

\section{Pembuatan karboksimetil kitin}

Kitin yang telah diperoleh digiling menjadi bubuk kitin, kemudian dilakukan alkalinisasi dengan menggunakan $\mathrm{NaOH} 50 \%$ sambil diaduk selama 3 jam pada suhu kamar dan dibekukan dengan menggunakan freezer pada suhu $\pm-4^{\circ} \mathrm{C}$ semalam. Alkali kitin kemudian dibiarkan mencair kembali pada suhu kamar kemudian ditambah isopropanol dengan 
perbandingan 1:1, diaduk satu jam dan disaring (Sheng et al., 2001). Alkali kitin kemudian ditambah asam monokloro asetat sebanyak 0,15 mol (13,96 gram), $0,30 \mathrm{~mol}(27,98$ gram) dan $0,45 \mathrm{~mol}(41,89$ gram) tiap $\mathrm{N}$ asetil glukosamin. Penambahan dilakukan sedikit demi sedikit sambil diaduk selama 1 jam dan didiamkan pada suhu kamar selama 24 jam. Kitin kemudian diatur $\mathrm{pH}$-nya sampai $7-8$ dengan menambahkan asam asetat $10 \%$, diencerkan dengan menggunakan air, kemudian disaring dengan kain saring. Filtrat yang diperoleh diendapkan menggunakan pelarut organik metanol atau isopropanol kemudian dikeringkan dalam oven $50-60^{\circ} \mathrm{C}$ selama 48 jam. Skema pembuatan karboksimetil kitin dapat dilihat pada Gambar 1.

\section{Pengamatan}

Pengamatan dilakukan terhadap kitin dan karboksimetil kitin yang diperoleh. Terhadap kitin

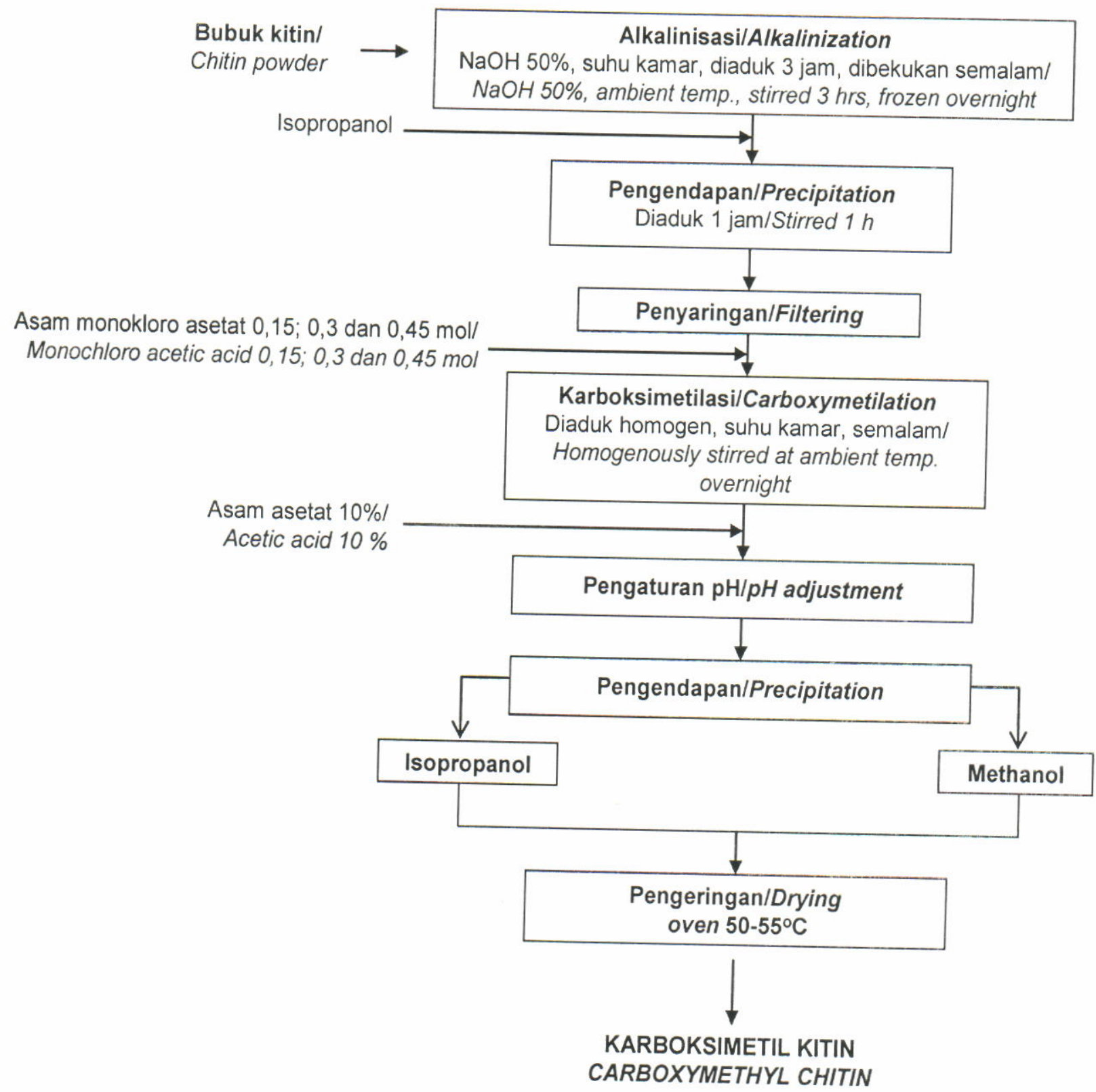

Gambar 1. Skema pembuatan karboksimetil kitin.

Figure 1. Schema of carboxymethyl chitin production. 
diamati rendemen, mutu organoleptik (bentuk dan warna), pengukuran derajat deasetilasi, kadar air,dan kadar abu (AOAC, 1984). Pengukuran derajat deasetilasi dilakukan untuk mengetahui bahwa produk yang diproses tersebut adalah kitin. Derajat deasetilasi kitin harus berkisar antara 15-70\% (Bustaman, 1989). Pengukuran derajat deasetilasi dilakukan dengan menggunakan Fourir Transform Infra Red-FTIR (Robert, 1997). Spektrum diambil dengan scanning pada daerah bilangan gelombang 4000 $\mathrm{cm}^{-1}$ sampai $600 \mathrm{~cm}^{-1}$. Derajat deasetilasi diukur dengan menggunakan metode base line. Untuk perhitungan dengan metode base line, puncak tertinggi diukur dan dicatat dari garis yang diperoleh, dan absorpsi dihitung dengan rumus (1). Untuk derajat deasetilasi, penentuan dan perhitungan dilakukan pada nilai absorbansi $1655 \mathrm{~cm}^{-1}$ dan nilai absorbansi $3450 \mathrm{~cm}^{-1}$ dengan rumus (2).

$$
A=\log \frac{P O}{P}
$$

Keterangan:

$\mathrm{Po}=$ Jarak antara garis dasar dengan garis singgung

$\mathrm{P}=$ Jarak antara garis dasar dengan puncak

$\% N-$ deasetilasi $=\left[1-\left(\frac{\mathrm{A}_{1655}}{\mathrm{~A}_{3450}} \times \frac{1}{1,33}\right)\right] \times 100 \%$

Keterangan:

$A_{1655}=$ Nilai absorbansi pada $1655 \mathrm{~cm}^{-1}$

$A_{3450}=$ Nilai Absorbansi pada $3450 \mathrm{~cm}^{-1}$

$1,33=$ Rasio $A_{1655}$ dengan $A_{3450}$ pada $N$-deasetilasi $100 \%$

Terhadap karboksimetil kitin dilakukan analisis gugus fungsi dengan membandingkan spektrum infra merah kitin menggunakan FTIR yang pengukuran derajat deasetilasinya dilakukan dengan menggunakan metode yang sama dengan kitin. Derajat substitusi untuk mengetahui jumlah gugus hidroksil pada satuan $\mathrm{N}$-asetil-glukosamin yang disubstitusi oleh gugus karboksimetil, ditentukan dengan metode titrasi bebas air menggunakan asam perklorat $0,1 \mathrm{~N}$ dalam dioksan (AOAC, 1984); dan penentuan kelarutan dilakukan dengan melarutkan karboksimetil dalam air pada suhu kamar dengan menggunakan metode gravimetri (AOAC, 1984). Kekentalan diukur pada larutan karboksimetil kitin 1\% pada suhu $20^{\circ} \mathrm{C}$ dengan menggunakan Viskometer Brookfield. Kadar air dan kadar abu dianalisis menggunakan metode AOAC (1984). Percobaan dilakukan dengan 2 kali ulangan.

\section{HASIL DAN BAHASAN}

\section{Kitin}

Rendemen kitin yang diperoleh dalam penelitian ini berkisar antara $14,7-14,8 \%$. Secara teoritis cangkang rajungan mengandung $15-20 \%$ kitin (Whistler \& Miller, 1973). Rendahnya rendemen kitin yang dihasilkan dapat disebabkan oleh beberapa faktor selama proses pengolahan, seperti pencucian dan pengeringan yang memungkinkan hilangnya kitin selama proses tersebut di atas. Kitin tidak larut dalam air, larutan basa yang encer, dan pekat, larutan asam encer dan pelarut organik lainnya. Akan tetapi kitin larut dalam asam-asam mineral pekat seperti asam klorida, asam sulfat, asam nitrat, asam fosfat, dan asam asetat anhidrat (Seichi \& Nishi, 1995). Diduga hilangnya kitin terjadi pada proses demineralisasi. Dalam proses ini konsentrasi $\mathrm{HCl}$ yang digunakan sebesar $10 \%$, sedangkan waktu perendaman 5 jam. Dalam proses ini kemungkinan sebagian kitin larut mengingat bahwa kitin dapat larut dalam asam klorida

Tabel 1. Karakteristik kitin yang diolah dari cangkang rajungan

Table 1. Chitin characteristics processed from swim crab shell

\begin{tabular}{lcc}
\hline \multicolumn{1}{c}{ Parameter/Parameters } & $\begin{array}{c}\text { Kitin hasil } \\
\text { percobaan/ } \\
\text { Chitin from } \\
\text { experiment }\end{array}$ & $\begin{array}{c}\text { Persyaratan kitin }{ }^{*} \text { ) } \\
\text { Requirement for chitin *) }\end{array}$ \\
\hline Rendemen/Yield & $14.67-14.83 \%$ & Serbuk/Powder \\
Bentuk/Shape & Putih/White & Putih/White \\
Warna/Colour & 33.51 & $15.0 \leq X \leq 70.0$ \\
Derajat deasetilasi/Degree of deacetylation (\%) & 8.04 & $\leq 10$ \\
Kadar air/Moisture content (\%) & 0.65 & $\leq 2.0$ \\
Kadar abu/Ash content $(\%)$ & & \\
\hline
\end{tabular}

*) Anon. (2003) 
pekat, sehingga menyebabkan rendahnya rendemen kitin yang dihasilkan.

Karakteristik kitin diamati secara organoleptik (bentuk dan warna), derajat deasetilasi, kadar air, dan abu (Tabel 1). Semua parameter kitin hasil percobaan memenuhi persyaratan standar kitin. Pada penelitian ini diperoleh derajat deasetilasi kitin 33,5\% yang tergolong rendah tetapi sudah memenuhi persyaratan kitin yang distandarkan dalam dunia perdagangan (15$70 \%$ ). Kadar air dan kadar abu kitin yang akan digunakan sebagai bahan dasar untuk pembuatan karboksimetil kitin masing-masing 8,0\% dan 0,7\%. Dengan demikian kitin yang diperoleh dapat digunakan sebagai bahan untuk penelitian selanjutnya.

\section{Karboksimetil Kitin}

\section{Identifikasi karboksimetil kitin}

Identifikasi gugus fungsi karboksimetil dilakukan menggunakan FTIR dengan membandingkan spektrum infra merah kitin dan karboksimetil kitin untuk melihat terjadinya eterifikasi (Gambar 2). Gambar 2 menunjukkan spektrum gugus fungsional salah satu kitin yang diberi perlakuan eterifikasi dengan 0,30 mol asam monokloro asetat dan pelarut organik isopropanol dengan kitin yang tidak diberi perlakuan. Kedua spektrum tersebut menghasilkan serapan yang tajam pada $3428-3445 \mathrm{~cm}^{-1}$ yang menunjukkan adanya gugus hidroksil $(\mathrm{OH})$. Pada kitin terdapat serapan pada bilangan gelombang 1660 $\mathrm{cm}^{-1}$ yang menunjukkan adanya gugus karbonil $(\mathrm{C}=\mathrm{O})$ sedangkan pada karboksimetil kitin tidak ada. Pada kedua spektrum terdapat serapan pada 1557-1558 $\mathrm{cm}^{-1}$ yang menunjukkan adanya gugus $\mathrm{NH}$ (amida). Sedangkan spektrum karboksimetil kitin memperlihatkan adanya puncak pada bilangan gelombang $1415 \mathrm{~cm}^{-1}$ yang diserap kuat, yang menunjukkan adanya gugus asetil $\left(\mathrm{CH}_{3}-\mathrm{COOH}\right)$ (Pine et al., 1988), yang pada kitin, puncak tersebut tidak ada. Perlakuan penambahan asam monokloro asetat pada kitin akan menyebabkan terjadinya eterifikasi gugus karboksilat dari asam monokloro asetat yang akan mensubstitusi gugus $\mathrm{Na}^{+}$pada alkoksida kitin menjadi karboksimetil kitin. Rincian bilangan gelombang dan gugus fungsi pada spektrum kitin dan karboksimetil kitin dapat dilihat dalam Tabel 2.

\section{Rendemen karboksimetil kitin}

Rendemen karboksimetil kitin yang dihasilkan dalam penelitian ini berkisar antara 37,5-81,4\% seperti yang disajikan dalam Gambar 3. Pada perlakuan peningkatan konsentrasi asam monokloro asetat dalam penelitian ini diharapkan bahwa semakin tinggi konsentrasi yang digunakan akan semakin banyak pula jumlah gugus karboksil dari monokloro asetat yang akan mensubtitusi ion $\mathrm{Na}^{+}$pada gugus COO-Na+ pada alkoksida kitin menjadi karboksimetil kitin. Peningkatan konsentrasi asam monokloro asetat akan meningkatkan gugus karboksil, yang menyebabkan lebih bersifat larut air. Karboksimetil kitin kemudian diendapkan dengan menggunakan pelarut metanol atau isopropanol.

Dalam penelitian ini pengendapan dengan isopropanol menghasilkan karboksimetil kitin yang meningkat sejalan dengan meningkatnya konsentrasi asam monokloro asetat. Sedangkan bila pengendapan dilakukan dengan pelarut metanol, maka semakin tinggi konsentrasi asam monokloro asetat semakin menurun rendemen yang dihasilkan. Semakin banyak substitusi gugus karboksil yang bersifat larut air rendemennya akan semakin kecil. Hal ini dapat dikaitkan dengan tingkat kepolaran bahan pengendap yang digunakan. Isopropanol merupakan senyawa yang kurang polar dibandingkan metanol. Penggunaan kedua pelarut tersebut dimaksudkan untuk mengikat gugus hidroksil dari karboksimetil kitin melalui ikatan hidrogen sehingga air keluar dari rantai polimer tersebut (Pine et al., 1988). Isopropanol akan menarik air, sementara itu karboksimetil kitin memiliki polaritas lebih rendah, dengan demikian karboksimetil kitin yang tidak mengikat gugus hidroksil akan mengendap. Sedangkan metanol memiliki sifat

Tabel 2. Bilangan gelombang dan gugus fungsi spektra inframerah kitin dan karboksimetil kitin Table 2. Wave number and functional group on infrared spectra of chitin and carboxymethyl chitin

\begin{tabular}{cccc}
\hline $\begin{array}{c}\text { Bilangan gelombang }\left(\mathrm{cm}^{-1}\right) / \\
\text { Wave number }\left(\mathrm{cm}^{-1}\right)\end{array}$ & $\begin{array}{c}\text { Gugus fungsi/ } \\
\text { Functional } \\
\text { group }\end{array}$ & $\begin{array}{c}\text { Kitin/ } \\
\text { Chitin }\end{array}$ & $\begin{array}{c}\text { Karboksimetil kitin/ } \\
\text { Carboxymethyl Chitin }\end{array}$ \\
\hline $3428-3445$ & Hydroxy $(\mathrm{OH})$ & Kuat/Strong & Kuat/Strong \\
1660 & Carbonil $(\mathrm{C}=\mathrm{O})$ & Kuat/Strong & - \\
$1557-1558$ & Amina $\left(\mathrm{NH}_{2}\right)$ & Kuat/Strong & Kuat/Strong \\
1415 & Carboxyl $(\mathrm{COO})$ & - & Kuat/Strong \\
\hline
\end{tabular}



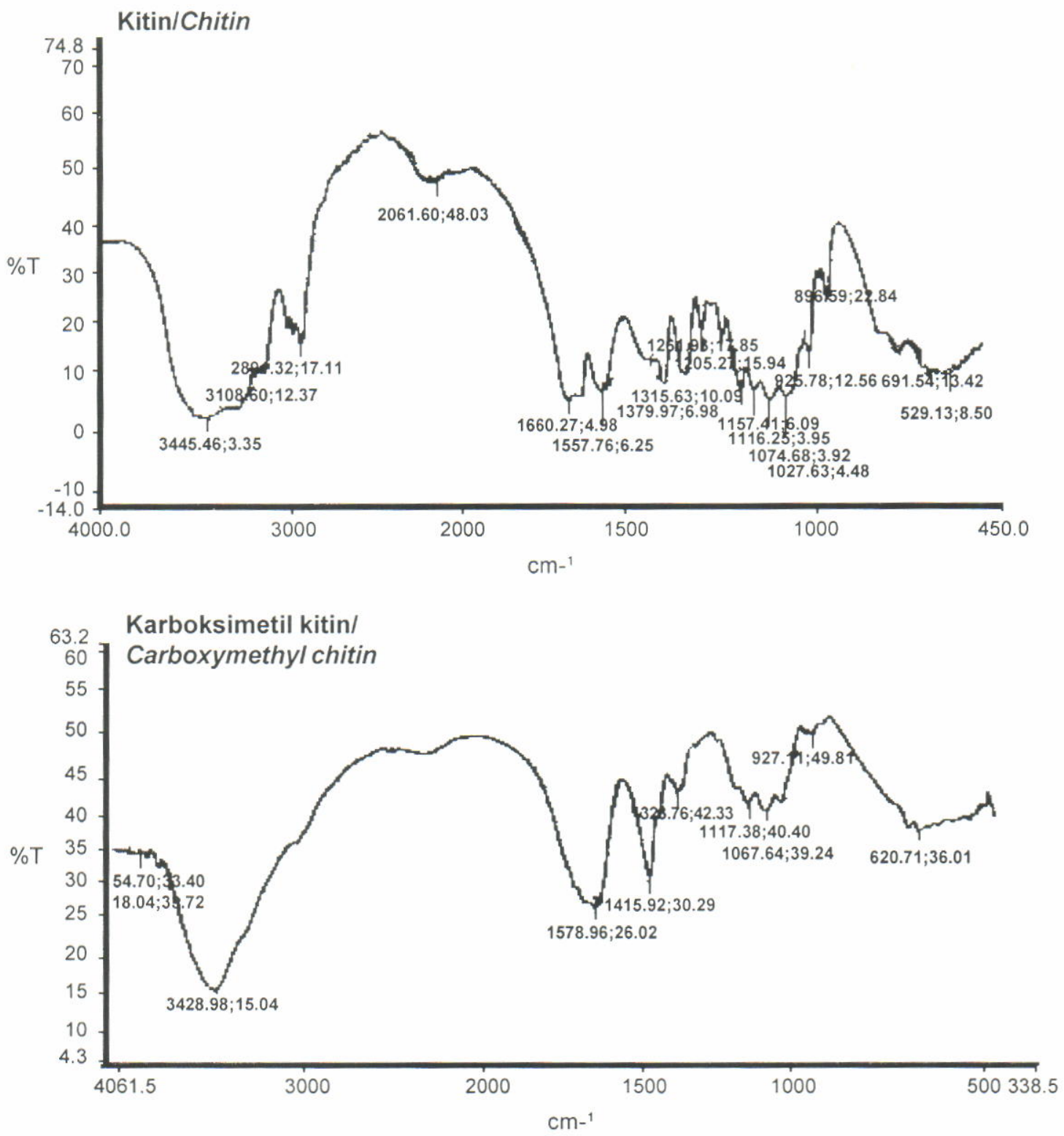

Gambar 2. Spektrum Infrared kitin dan karboksimetil kitin.

Figure 2. Infrared spectrum of chitin and carboxymethyl chitin.

polaritas yang lebih tinggi dari isopropanol sehingga akan lebih sedikit menarik air. Di lain pihak karboksimetil kitin bersifat larut air, sehingga penggunaan metanol sebagai bahan pengendap kurang begitu efektif karena akan melarutkan karboksimetil kitin tersebut. Hal ini karena masih banyak gugus hidroksil pada karboksimetil kitin yang tidak dapat diikat sehingga tidak dapat mengendap. Dengan demikian pada penggunaan pelarut organik yang bersifat non-polar, semakin besar mol yang ditambahkan akan semakin banyak rendemen yang dihasilkan.

\section{Derajat deasetilasi karboksimetil kitin}

Hasil analisis derajat deasetilasi terhadap karboksimetil kitin pada berbagai perlakuan dapat dilihat pada Gambar 4. Perlakuan tingkat konsentrasi asam monokloro asetat yang digunakan berpengaruh terhadap peningkatan derajat deasetilasi yang lebih tinggi. Derajat deasetilasi karboksimetil kitin dalam penelitian ini berkisar antara $44,4-59,3 \%$, meningkat bila dibandingkan dengan derajat deasetilasi kitin yang digunakan, yaitu $33,5 \%$, dan berbeda dengan karboksimetil kitosan yang derajat deasetilasinya 

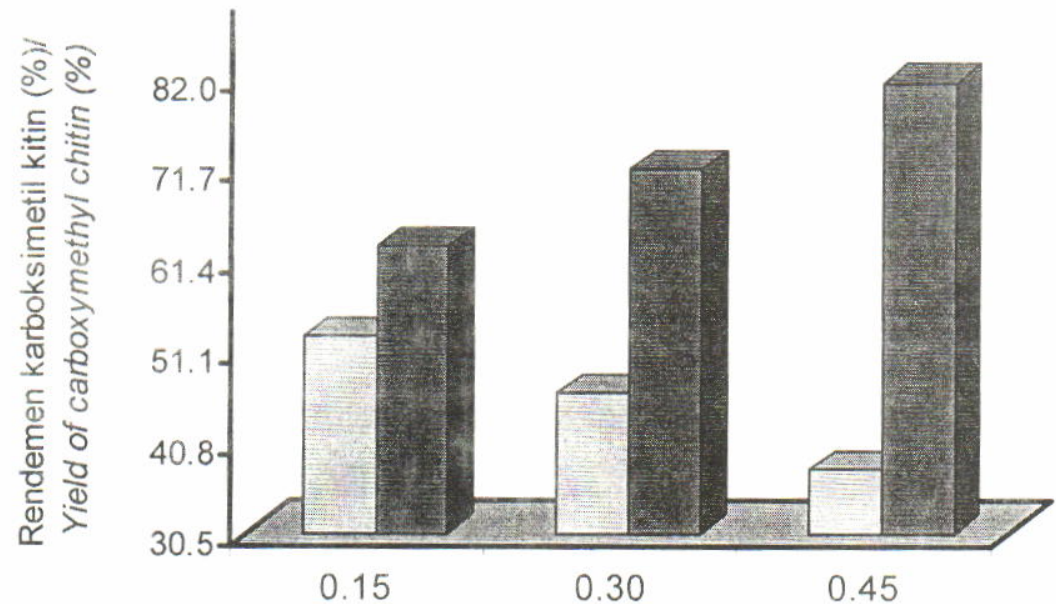

$\square$ Metanol/Methanol

늠 Isopropanol

Jumlah mol asam monokloro asetat/

Total mol of monochloro acetic acid

Gambar 3. Rendemen karboksimetil kitin.

Figure 3. Yield of carboxymethyl chitin.

dapat mencapai lebih dari $90 \%$ seperti hasil penelitian Dwiyitno et al. (2004).

Dalam penelitian ini suhu yang digunakan adalah suhu beku $\left(-4^{\circ} \mathrm{C}\right)$ dengan pengadukan selama 3 jam untuk memungkinkan terjadinya substitusi gugus karbonil dari asam monokloro asetat dengan alkoksida kitin menjadi karboksimetil kitin. Penyimpanan suhu beku dilakukan untuk menghidari terjadinya depolimerisasi dan derajat deasetilasi lebih dari 70\% sehingga tidak menjadi kitosan.

Perendaman dalam $\mathrm{NaOH}$ dilakukan terhadap sampel kitin yang sudah berbentuk bubuk. Menurut Win \& Steven (2001), dalam bentuk bubuk proses deasetilasi dapat berjalan lebih efisien, walaupun proses deasetilasi dilakukan pada suhu beku. Suhu dan waktu perendaman dalam $\mathrm{NaOH}$ menentukan

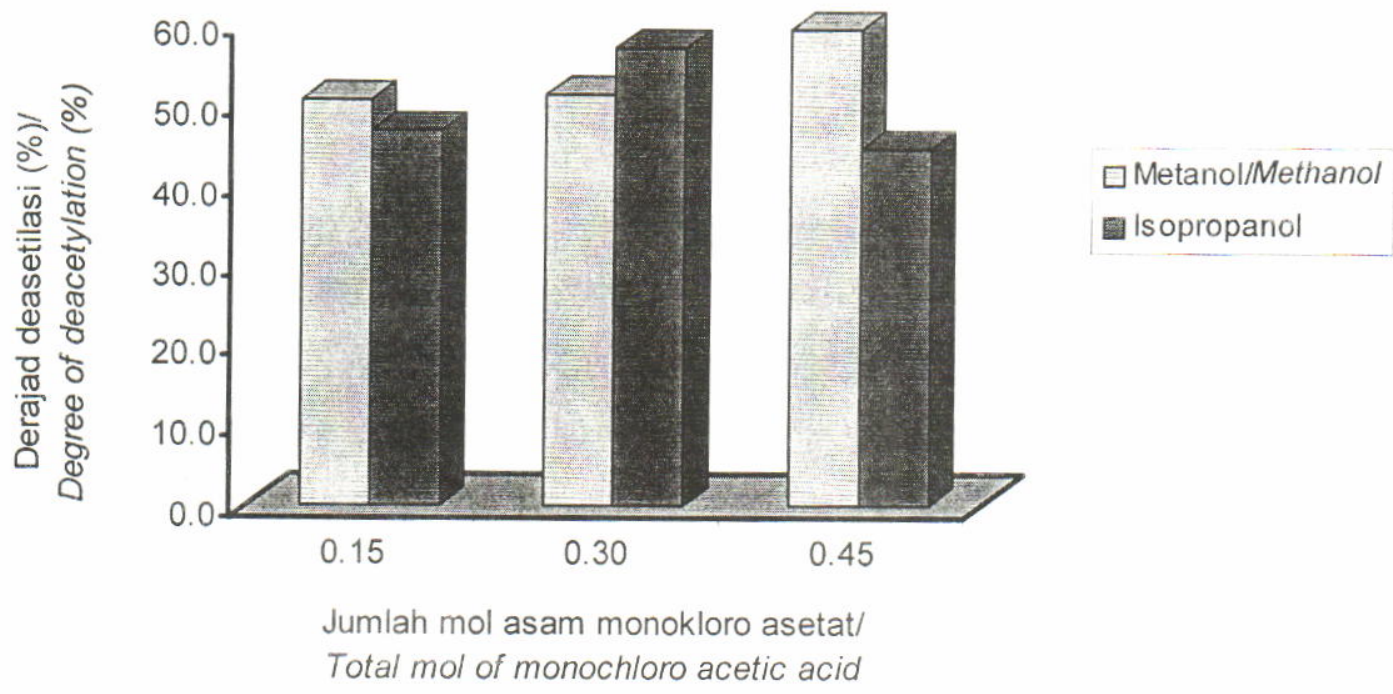

Gambar 4. Derajat deasetilasi karboksimetil kitin.

Figure 4. Degree of deacetylation of carboxymethyl chitin. 
derajat deasetilasi, semakin tinggi suhu dan lama waktu perendaman maka derajat deasetilasinya semakin tinggi (Kolodziejska et al., 2000).

Pada pengendapan dengan metanol, perlakuan konsentrasi asam monokloro asetat menunjukkan bahwa semakin tinggi konsentrasi asam monokloro asetat yang digunakan semakin besar pula derajat deasetilasi yang diperoleh. Sedangkan pada pengendapan dengan isopropanol, semakin besar jumlah mol asam monokloro asetat yang digunakan berpengaruh fluktuatif terhadap derajat deasetilasi yang digunakan, yaitu meningkat pada konsentrasi 0,15 mol-0,30 mol, tetapi kemudian menurun pada konsentrasi 0,45 mol. Pengendapan dengan menggunakan metanol menghasilkan derajat deasetilasi yang lebih besar dibandingkan dengan isopropanol. Rata-rata derajat deasetilasi yang diendapkan dengan metanol sebesar 53,8\% sedangkan bila diendapkan dengan isopropanol sebesar $49,5 \%$.

\section{Derajat substitusi}

Hasil analisis derajat substitusi dapat dilihat pada Gambar 5. Derajat substitusi ini menunjukkan jumlah gugus hidroksil pada satuan $\mathrm{N}$-asetil-glukosamin yang disubstitusi oleh gugus karboksimetil. Semakin besar konsentrasi asam monokloro asetat yang digunakan semakin meningkat pula derajat substitusi yang dihasilkan. Hal ini menunjukkan bahwa semakin tinggi konsentrasi asam monokloro asetat semakin banyak gugus hidroksil yang disubstitusi oleh gugus karboksimetil dari asam monokloro asetat. Rata-rata derajat substitusi yang mendapat perlakuan asam monokloro asetat 0,15 mol sebesar 0,7 naik menjadi 0,8 jika diberi perlakuan asam monokloro asetat 0,30 mol dan menjadi 0,9 jika diberi perlakuan asam monokloro asetat 0,45 mol. Namun demikian peningkatan jumlah asam monokloro asetat tidak selalu menghasilkan derajat substitusi tinggi.

Derajat substitusi dipengaruhi oleh pembentukan alkoksida kitin yaitu gugus hidroksil dari kitin yang merupakan asam lemah disubstitusi oleh $\mathrm{Na}^{+}$dari $\mathrm{NaOH}$ pada proses alkalinisasi. Sedangkan proses alkalinisasi sendiri dipengaruhi oleh suhu dan konsentrasi $\mathrm{NaOH}$ yang digunakan. Semakin tinggi konsentrasi $\mathrm{NaOH}$ yang digunakan semakin tinggi produksi alkoksidanya. Proses alkalinisasi dapat dilakukan menggunakan $\mathrm{NaOH} 30-50 \%$ pada suhu $60-140^{\circ} \mathrm{C}$ (Kolodziejska et al., 2000).

Pelarut organik isopropanol dan metanol digunakan untuk mengendapkan karboksimetil kitin. Penggunaan pelarut organik isopropanol sebagai bahan pengendap menghasilkan derajat substitusi yang sedikit lebih besar bila dibandingkan dengan menggunakan metanol. Rata-rata derajat substitusi karboksimetil kitin yang diendapkan dengan metanol adalah 0,78 sedangkan bila diendapkan dengan isopropanol 0,83.

\section{Kelarutan dalam air}

Suatu senyawa dikatakan larut bila bagian pelarut yang diperlukan untuk melarutkan $1 \mathrm{gram}$ zat berkisar

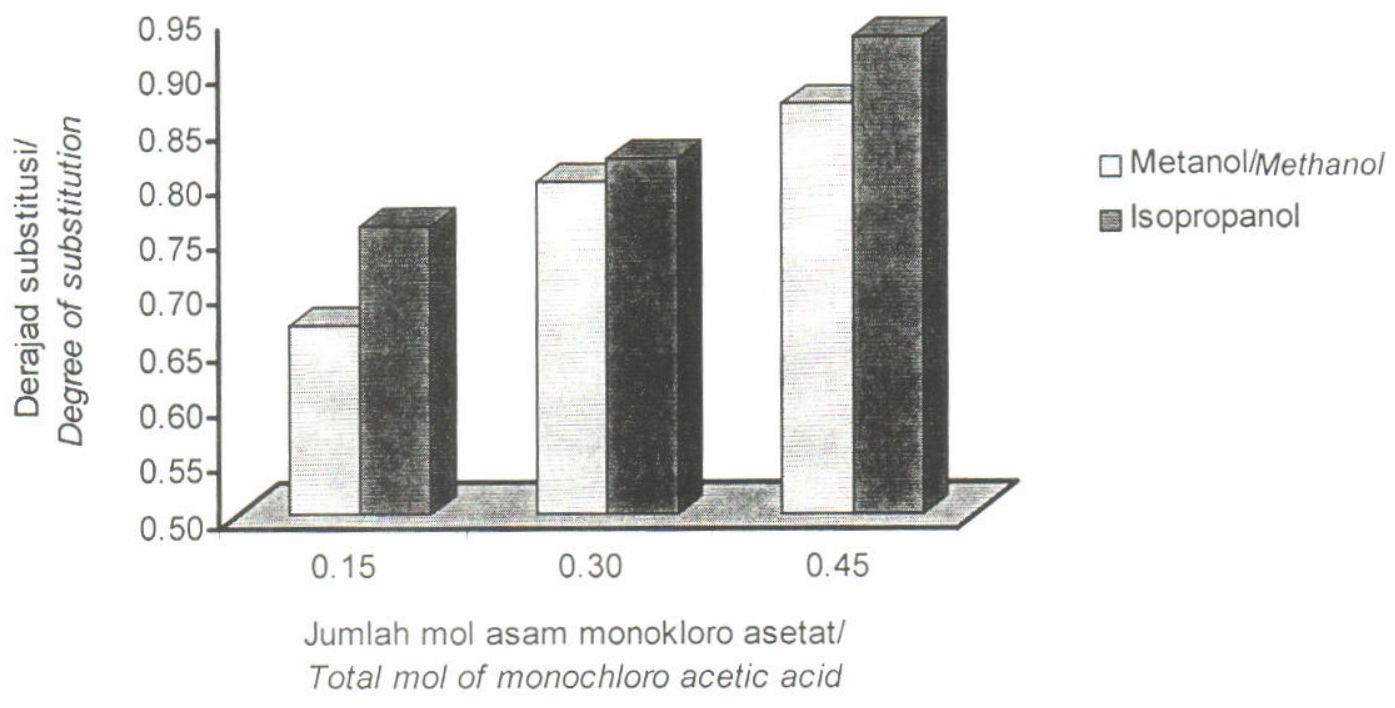

Gambar 5. Derajat substitusi karboksimetil kitin.

Figure 5. Degree of substitution of carboxymethyl chitin. 


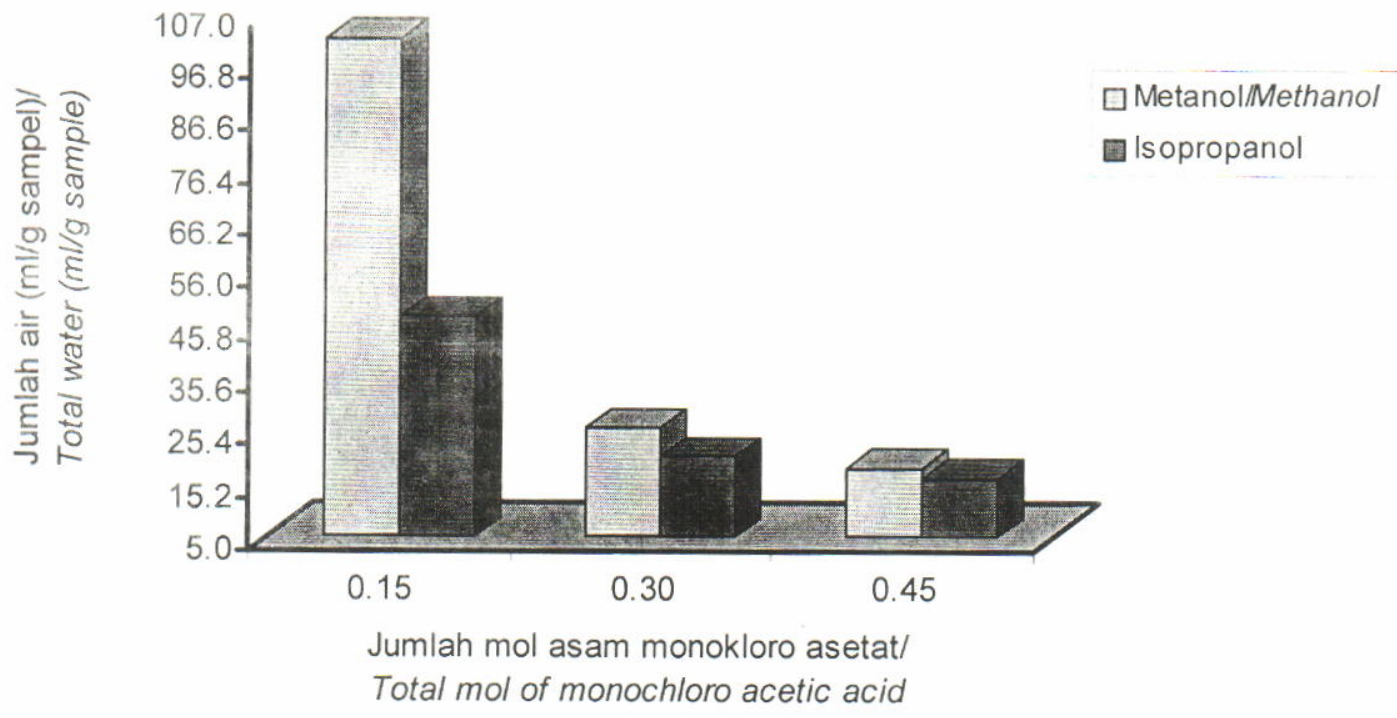

Gambar 6. Kelarutan karbosimetil kitin dalam air. Figure 6. Water solubility of carboxymethyl chitin.

antara 10-30 ml (Anon., 1995) sehingga semakin kecil jumlah air sebagai pelarut maka makin tinggi tingkat kelarutannya. Dalam penelitian ini kelarutan diukur dengan menghitung jumlah pelarut air yang dibutuhkan untuk melarutkan 1 gram zat.

Hasil analisis kelarutan karboksimetil kitin dapat dilihat pada Gambar 6. Kelarutan karboksimetil kitin dalam air meningkat sesuai dengan penambahan asam monokloro asetat yang digunakan. Semakin besar konsentrasi asam monokloro asetat semakin besar pula terjadinya substitusi gugus karboksil dari monokloro asetat pada gugus alkali kitin. Adanya gugus karboksil ini menyebabkan karboksimetil kitin mudah larut (Crowd \& Stark, 1991). Pengendapan dengan isopropanol menghasilkan karboksimetil kitin yang kelarutannya dalam air lebih tinggi bila dibandingkan dengan metanol. Dalam penelitian ini karboksimetil kitin yang diperoleh dengan menggunakan asam monokloro asetat 0,30 dan 0,45 mol dapat dikategorikan sebagai senyawa yang larut air. Karboksimetil kitin dari kedua perlakuan tersebut dapat larut pada air dengan volume kurang dari $30 \mathrm{ml}$. Sedangkan penggunaan asam monokloro asetat 0,15 mol, memberikan kelarutan yang relatif kecil pada karboksimetil kitin yang dihasilkan. Hal ini disebabkan karena jumlah gugus karboksimetil yang tersubstitusi tidak mencukupi untuk membuat kitin lebih larut dalam air.

\section{Kekentalan}

Hasil analisis kekentalan karboksimetil kitin dapat dilihat pada Gambar 7. Kekentalan karboksimetil kitin berbeda-beda tergantung bahan pengendap dan konsentrasi asam monokloro asetat yang digunakan. Pada metanol, semakin besar konsentrasi asam monokloro asetat yang digunakan, semakin meningkat kekentalan yang diperoleh. Dengan pelarut metanol sebagai pengendap, kekentalan karboksimetil kitin tertinggi diperoleh dari penambahan asam monokloro asetat 0,45 mol yaitu sebesar $148,8 \mathrm{cPs}$. Hasil penelitian ini tidak jauh berbeda dengan kekentalan karboksimetil kitosan hasil penelitian Prasetyo (2004), yang menggunakan perlakuan kitosan : monokloro asetat 1:0,9 yang dieterifikasi pada suhu $60^{\circ} \mathrm{C}$, yaitu sebesar $137,2 \mathrm{cPs}$. Sebaliknya, jika pelarut organik sebagai pengendap yang digunakan adalah isopropanol maka semakin besar konsentrasi yang digunakan semakin kecil tingkat kekentalan karboksimetil kitin yang hanya berkisar antara $15,75-58,75 \mathrm{cPs}$.

Nilai kekentalan kitin dipengaruhi oleh derajat deasetilasi, berat molekul, kekuatan ion, $\mathrm{pH}$ dan suhu saat pengukuran (Dunn et al., 1997). Semakin besar berat molekul dan panjang rantai polimer maka larutan tersebut akan semakin kental. Dalam penelitian ini diduga penggunaan isopropanol untuk menarik gugus hidroksil pada rantai molekul karboksimetil kitin dapat menyebabkan terjadinya fragmentasi rantai polimer sehingga menghasilkan rantai polimer karboksimetil yang lebih pendek.

Standar kekentalan untuk karboksilmetil kitin yang digunakan dalam perdagangan adalah $100 \mathrm{cPs}$ atau lebih. Dengan demikian hanya perlakuan konsentrasi 0,30 dan $0,45 \mathrm{~mol}$ dengan pengendap organik metanol 


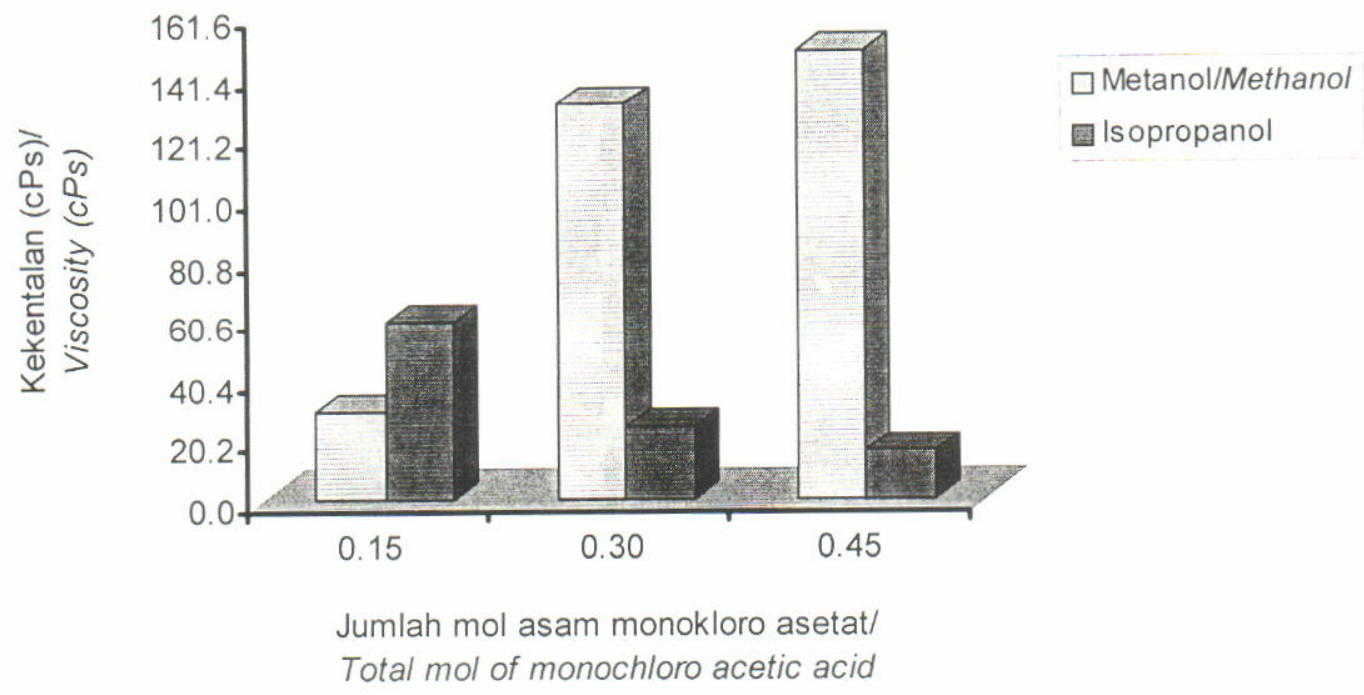

Gambar 7. Kekentalan karboksimetil kitin.

Figure 7. Viscosity of carboxymethyl chitin.

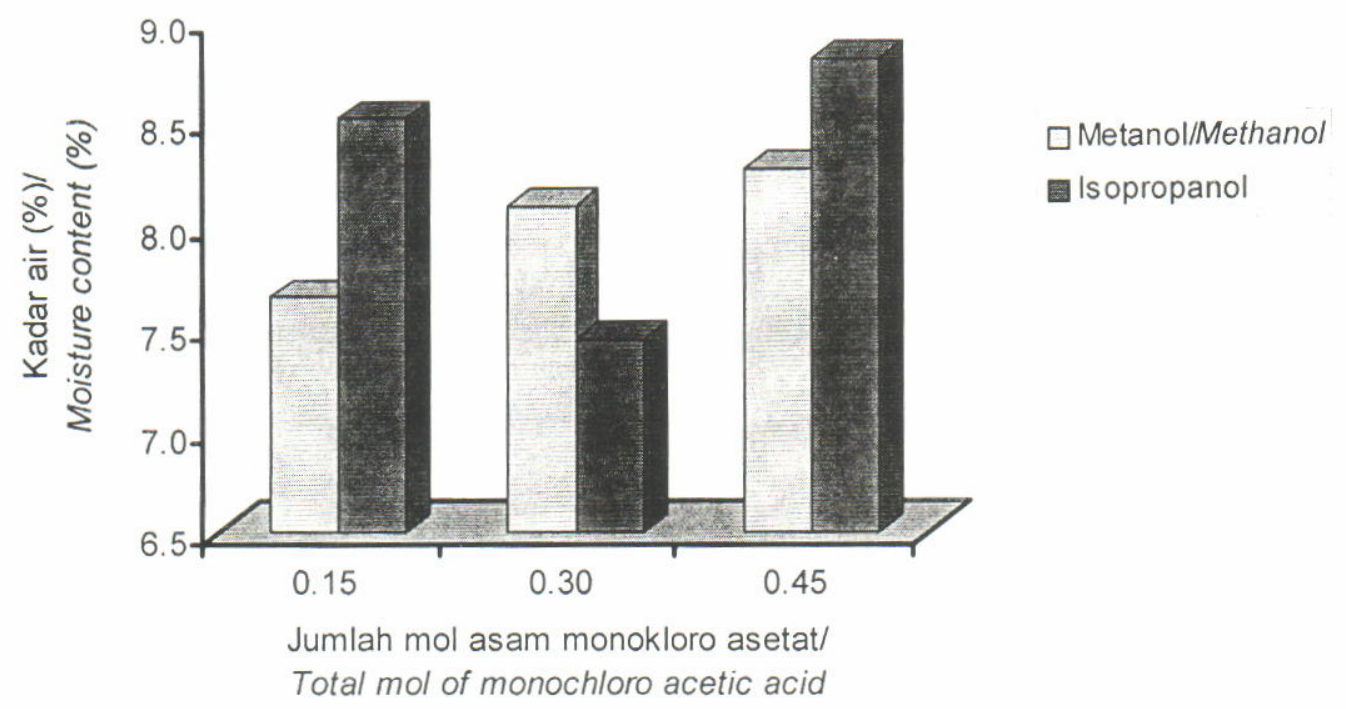

Gambar 8. Kadar air karboksimetil kitin.

Figure 8. Moisture content of carboxymethyl chitin.

yang memenuhi persyaratan perdagangan untuk kekentalan karboksimetil kitin.

\section{Kadar air}

Hasil analisis kadar air karboksimetil kitin yang diperoleh berkisar antara 7,4-8,9\% (Gambar 8), tidak jauh berbeda dengan kadar air kitin yang digunakan yaitu sebesar $8,0 \%$. Perlakuan yang diberikan, baik konsentrasi asam monokloro asetat maupun perbedaan jenis larutan pengendap tidak berpengaruh terhadap kadar air yang dihasilkan. Hasil penelitian juga menunjukkan bahwa tingkat kekeringan karboksimetil kitin yang diperoleh memenuhi persyaratan kadar air karboksimetil kitin dalam perdagangan yaitu sebesar $16 \%$.

\section{Kadar abu}

Hasil pengamatan kadar abu karboksimetil kitin dapat dilihat dalam Gambar 9. Hasil analisis kadar abu menunjukkan bahwa jumlah asam monokloro 


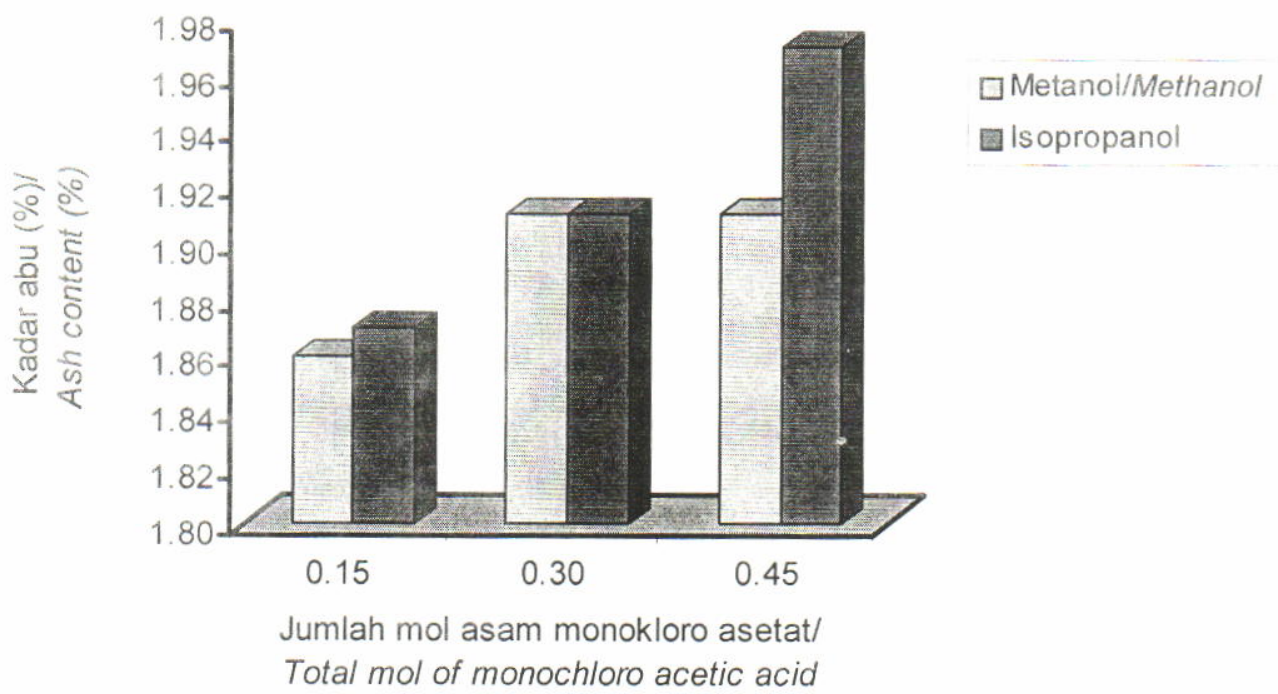

Gambar 9. Kadar abu karboksimetil kitin

Figure 9. Ash content of carboxymethyl chitin

asetat dan perbedaan pelarut organik sebagai bahan pengendap tidak memberikan pengaruh yang nyata terhadap kadar abu karboksimetil kitin yang dihasilkan. Dibandingkan dengan kadar abu kitin yang digunakan sebagai bahan baku, kadar abu karboksimetil kitin ini meningkat. Hal ini diduga berasal dari natrium hidroksida yang digunakan pada proses pembentukan alkoksida yang merupakan senyawa yang tidak menguap selama pengabuan.

\section{KESIMPULAN}

Dari hasil penelitian ini dapat disimpulkan bahwa semakin tinggi konsentrasi asam monokloro asetat yang digunakan akan menghasilkan rendemen karboksimetil kitin, derajat substitusi, kelarutan, dan kekentalan yang lebih baik. Penggunaan pelarut isopropanol sebagai pengendap menghasilkan rendemen, derajat substitusi dan kelarutan yang lebih baik dibandingkan dengan metanol. Perlakuan terbaik yang digunakan dalam penelitian ini diperoleh dari penggunaan 0,30 mol asam monokloro asetat dan pelarut organik pengendap metanol, yang menghasilkan rendemen karboksimetil kitin sebesar $46,4 \%$, derajat deasetilasi $51,4 \%$, derajat substitusi 0,8 , kelarutan memerlukan air $26,3 \mathrm{ml} / \mathrm{g}$ sampel, kekentalan $131,3 \mathrm{cPs}$, kadar air $8,1 \%$, dan kadar abu $1,9 \%$.

\section{DAFTAR PUSTAKA}

Anonymous. 1981. Committee on Codex Specification. Food Chemical Codex. $3^{\text {rd }}$ ed. Washington D.C. National Academic Press. p. 550-551.
Anonymous. 2003. Specification of Carboxymethylchitosan. Http://www.chitin. ns.ca.apllicat.htm. 6 pp.

Anonim. 1995. Farmakope Indonesia. Direktorat Jenderal Pengawasan Obat dan Makanan. Departemen Kesehatan Republik Indonesia. 11 pp.

AOAC. 1984. Official Methods of Analysis of the Association of Official Analytical Chemist. 14th ed. A.O.A.C. Inc. Arlington. Virginia.

Bader, H.J. and Birkholz, E. 1997. Teaching Chitin Chemistry. In Muzzarelli, R.A.A. and Peter, M.G. (eds.). Chitin Handbook. European Chitin Society. p. 507-519.

Bustaman, S. 1989. Studies on Degradation Extraction of Chitin and Chitosan from Prawn Shell (Nephrops novergics). Thesis. Engineeing Faculty Qeen University. Belfast USA. 204 pp.

Crowd, M.A. dan Stark, J.G. 1991. Kimia Polimer. Terjemahan: Harry Firman. ITB. Bandung. 103 pp.

Dahuri, R. 2003. Keaneka Ragaman Hayati Laut. Penerbit Gramedia. Jakarta. 169 pp.

Dunn, E.T., Grandmaison, E.W. and Goosen, M.F.A. 1997. Applications and properties of chitosan. In Goosen, M.F.A. (ed.). Applications of Chitin and Chitosan. Technomic Publ. Co. In. Basel. p. 3-21

Dwiyitno, Basmal, J. dan Mulyasari. 2004. Pengaruh suhu esterifikasi terhadap karakteristik karboksimetil khitosan (CMCts). J. Penel. Perik. Indonesia. 10(3): 67-73.

Hirano, S. 1988. Production and application of chitin and chitosan in Japan. In Gudmund, Anthonsen, T., and Sanford, P. (eds.). Chitin and Chitosan. Elsevier Applied Science. London and New York. p. 37-4.

Hong, K.N. and Meyer, S.P. 1989. Isolation and characterization of chitin from rawfish shell waste. J. Agric. Food Chem. 37(3): 575-578.

Kolodziejska, I., Wojtasz, A.P., Ogonowska, G. and Sikorsi, Z.E. 2000. Deacetylation of chitin in two stage chemi- 
cal and enzymatic process. Bull. Sea Fisheries Inst. 2(150): 15-24.

Olsen, R., Schwartzmiller, D., Weppner, W. and Winandy, R. 1988. Biomedical, applications of chitin and its derivatives. In Gudmund, Anthonsen, T. and Sanford, P. (eds). Chitin and Chitosan. Elsevier Applied Science. London and New York. p. 813-828.

Peranginangin, R. 2004. Prospek Pengembangan Produk Baru dari Limbah Hasil Perikanan Sebagai Bahan Baku Sekunder. Orasi pengukuhan Ahli Peneliti Utama Bidang Pasca Panen Perikanan. Departemen Kelautan dan Perikanan. Badan Riset Kelautan dan Perikanan. 35 pp.

Pine, S.H., Hendrickson, J.B., Cram, D.J. and Hammond, G.S. 1988. Organic Chemistry. Fourh Edition. Mc Graw Hill, Inc. New Jersey. 617 pp.

Prasetyo, A. 2004. Pengaruh Penambahan Asam Monokloro Asetat dan Suhu pada Pembentukan Karboksimetil Kitosan yang Dihasilkan dari Kitosan yang Berasal dari Cangkang Rajungan (Portunus pelagicus). Skripsi. Universitas Pancasila. 75 pp.

Seichi, T. and Nishi, N.1995. Specification and Characterization of Chitin and Chitosan. Enviromentally Friendly Modern Matrics. Japan. p. 75-80.
Samarin, O., Nishi, N. and Tokura, S. 2001. Preparation and Some Properties of Water Soluble Chitin Derivates. Department of Polymer Science. Tokyo University. Japan. p. 54-56.

Shalaby, W.K. and Shah, R.K.1991. Chemical Modification of Natural Polymers and Their Technological Relevance. Bio Enginering Dept. Clemson University. American Chemical Society. p. 74-78.

Sheng, H.M., Ahn, B.J., Kim, Y.W. and Kim, B.J. 2001. The novel synthesis of carboxymethyl-chitin by new proccess. J. Korean Chemical Society. 45(4): 334339

Robert, G.A.F. 1997. Determination of the degree of $\mathrm{N}$ acetylations. In Skjak-Braek, G., Anthosen, T. and Sanford, P. (eds). Chitin and Chitosan. Source Chemistry, Biochemistry, Physical Properties and Application. Elsevier. London. 8 pp.

Win, N.N. and Steven, W.F. 2001. Shrimp chitin as substrate for fungal chitin deacetylase. Appl. Microbiol. Biotechnol. 57: 334-341.

Whistler, R.L. and Miller, B.1973. Industrial Gum, Polysacharides and Their Derivatives. Second edition. New York, AP Press. 475 pp. 